\title{
Theoretical Investigation of
}

\section{$N$-Methyl- $N^{\prime}$-(4-nitrobenzylidene) pyrazine-2-carbohydrazide: Conformational Study, NBO Analysis, Molecular Structure and NMR Spectra}

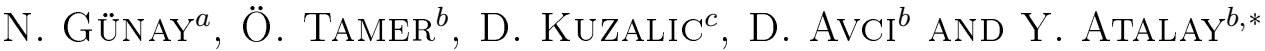 \\ ${ }^{a}$ Beykent University, Department of Health Programmes, Opticianry Programme, İstanbul, Turkey \\ ${ }^{b}$ Sakarya University, Faculty of Arts and Sciences, Department of Physics, 54187, Sakarya, Turkey \\ ${ }^{c}$ Beykent University,Faculty of Enginering, Department of Chemical Enginering, İstanbul, Turkey
}

(Received April 17, 2014; in final form January 23, 2015)

The crystal structure determination of the methylated pyrazine-2-carbohydrazide derivative, namely $N$ methyl- $N^{\prime}$-(4-nitrobenzylidene)pyrazine-2-carbohydrazide were optimized to obtain its molecular geometric structure and electronic structures at the Hartree-Fock and density functional theory levels (B3LYP) with 6-311G(d,p) and $6-311++\mathrm{G}(\mathrm{d}, \mathrm{p})$ basis sets, using Gaussian $09 \mathrm{~W}$ programme. The ${ }^{1} \mathrm{H}$ and ${ }^{13} \mathrm{C}$ nuclear magnetic resonance chemical shifts of the title molecule were calculated by using the gauge independent atomic orbital, continuous set of gauge transformations and individual gauges for atoms in molecules methods and were also compared with experimental values. The electronic properties high occupied and low unoccupied molecular orbitals energies were calculated and analyzed. Potential energy surface scan, natural population analysis and Mulliken atomic charges were investigated using theoretical calculations. A detailed molecular picture and intermolecular interactions arising from hyperconjugative interactions and charge delocalization of the molecule were analyzed using natural bond orbital analysis.

DOI: 10.12693/APhysPolA.127.701

PACS: 31.15.A-, 31.15.ae, 31.15.E-, 33.25.+k, 31.50.Bc

\section{Introduction}

Pyrazine is a symmetrical and heterocyclic aromatic organic compound having two nitrogen atoms in the para-position of the six-membered ring. Ligands containing pyrazine ring are widely studied and their pi-donor properties are interesting [1]. Pyrazine has been paid great attention, because the diazine rings form an important class of compounds presented in several natural and synthetic compounds [2]. Pyrazine derivatives have been widely used in the fields of medicinal chemistry for the skeleton of biologically active sites $[3,4]$. Pyrazines and its derivatives constitute an important class of compounds present in several natural flavours and complex organic molecules [5]. In continuation of these studies, the synthesis and antituberculosis activities of a series of methylated pyrazine-2-carbohydrazide derivatives have been studied [6-8]. Pyrazine derivatives are known as an important drugs with analgesic [9], antimicrobial [10], anticancer [11], sodium channel blocker [12], antiviral [13], antihypertensive [14], antiglaucoma [15], antioxidant [16], antidepressant, anxiolytic, neuroprotective [17] and antidiabetic [18] activity. Pyrazine-2-carbohydrazides have been the object of many spectral, structural and theoretical investigations [19-22]. However, to the best of our

\footnotetext{
${ }^{*}$ corresponding author; e-mail: yatalay@sakarya.edu.tr
}

knowledge, the theoretical investigations for structural, spectroscopic and electronic properties of $\mathrm{N}$-methyl$N^{\prime}$-(4-nitrobenzylidene) pyrazine-2-carbohydrazide compound have not been performed. So as to eliminate this deficiency, detailed theoretical investigations were carried out concerning the conformational analysis, vibrational frequencies and NMR chemical shifts, bonding features, high occupied molecular orbital (HOMO) and low unoccupied molecular orbital (LUMO) energies.

\section{Computational details}

The quantum chemical calculations have been performed by using the Hartree-Fock (HF) method and B3 [23] exchange functional combined with the LYP [24] correlation function resulting in the B3LYP density functional method combined with 6-311G(d,p) and 6$311++\mathrm{G}(\mathrm{d}, \mathrm{p})$ basis sets. All electronic and structural computations were performed using Gaussian $09 \mathrm{~W}$ program [25] and Gauss View 5.0 program package [26]. The potential energy surface was studied at the 6$311 \mathrm{G}(\mathrm{d}, \mathrm{p})$ level. NBO analyses $[27]$ have been performed by the module NBO version 3.1 implemented in Gaussian $09 \mathrm{~W}[25]$ at the optimization level to determine the partial charge distribution and the bonding characters of the title molecule. 


\section{Results and discussion}

\subsection{Molecular geometry}

In order to find the best optimized geometry the geometric parameters of the title compound were optimized using HF and B3LYP methods with 6-311G(d,p) (marked in Tables $A 1$ ) and $6-311++\mathrm{G}(\mathrm{d}, \mathrm{p})(A 2)$ basis sets. The atom numbering scheme for the molecule is shown in Fig. 1a [8]. The optimized geometry of the title molecule performed at B3LYP $/ 6-311++\mathrm{G}(\mathrm{d}, \mathrm{p})$ level with atoms numbering is shown in Fig. 1b.
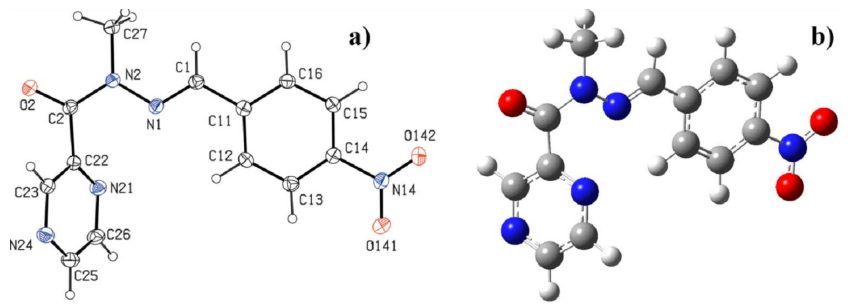

Fig. 1. (a) The experimental geometric structure [8], (b) optimized molecular structure (with B3LYP/6$311++\mathrm{G}(\mathrm{d}, \mathrm{p})$ level $)$ of the title compound.

The title molecule belongs to the $C 2 / c$ space group. The unit cell dimensions are $a=17.510(2) \AA, b=$ 10.5421(11) $\AA, c=14.9638(14) \AA$ and $V=2628.7(5) \AA^{3}$ and has eight formula units per unit cell $(Z=8)$. These results are taken from the data reported by Gomes et al. [8].

The optimized geometrical parameters (bond distances, bond angles and dihedral angles) are presented in Tables I-III and compared with the experimental X-ray diffraction [8] of a compound having similar structure. The correlation coefficient for the calculated and the experimental values of the molecule are shown in Tables.

The changes in the bond length of $\mathrm{C}-\mathrm{H}$ bond on substitution due to a change in the charge distribution on the carbon atom of the benzene ring [28]. The carbon atoms are bonded to the hydrogen atoms with $\sigma$-bond in benzene and substitution of $\mathrm{NO}_{2}$ group for hydrogen reduces the electron density at the ring carbon atom.

The bond length of $\mathrm{N}-\mathrm{O}$ in nitro group is somewhat different and it is due to the repulsion between the lone electron pair on the $\mathrm{O}$ atom and the electron pair on the nitrogen atom [29]. In the present work, the $\mathrm{C}-\mathrm{H}$ bond lengths were calculated in the range 1.0710-1.0939 $\AA$, experimentally the $\mathrm{C}-\mathrm{H}$ bond lengths are observed as 0.95 and $0.98 \AA$.

In substituted benzenes, the ring carbon atoms exert a large attraction on the valence electron cloud of the $\mathrm{H}$ atom resulting in an increase in the $\mathrm{C}-\mathrm{H}$ force constant and a decrease in the corresponding bond length [30]. The $\mathrm{C} 1-\mathrm{C} 11$ and $\mathrm{C} 2-\mathrm{C} 22$ bond distances are the longest while the other $\mathrm{C}-\mathrm{C}$ bond distances are shortest. The longest bond distance attributes the pure single bond character. In the benzene ring the $\mathrm{C} 11-\mathrm{C} 12$
TABLE I

The values of distances $(\AA)$ between atoms calculated for the title compound using B3LYP and HF methods compared with experimental data [8]

\begin{tabular}{|c|c|c|c|c|c|}
\hline & \multirow{2}{*}{$\begin{array}{l}\text { Exp. [8] } \\
A 1\end{array}$} & \multicolumn{2}{|c|}{ Calc. B3LYP } & \multicolumn{2}{|c|}{ Calc. HF } \\
\hline & & $A 2$ & $A 1$ & $A 2$ & \\
\hline $\mathrm{O} 2-\mathrm{C} 2$ & $1.224(2)$ & 1.2160 & 1.2167 & 1.1912 & 1.1922 \\
\hline O141-N14 & $1.231(2)$ & 1.2242 & 1.2254 & 1.1865 & 1.1874 \\
\hline O142-N14 & $1.225(2)$ & 1.2244 & 1.2256 & 1.1869 & 1.1878 \\
\hline N1-C1 & $1.278(3)$ & 1.2832 & 1.2835 & 1.2539 & 1.2543 \\
\hline $\mathrm{N} 1-\mathrm{N} 2$ & $1.379(2)$ & 1.3519 & 1.3539 & 1.3467 & 1.3478 \\
\hline $\mathrm{N} 2-\mathrm{C} 2$ & $1.369(2)$ & 1.3930 & 1.3910 & 1.3727 & 1.3711 \\
\hline $\mathrm{N} 2-\mathrm{C} 27$ & $1.458(2)$ & 1.4607 & 1.4605 & 1.4505 & 1.4507 \\
\hline N14-C14 & $1.470(2)$ & 1.4765 & 1.4760 & 1.4638 & 1.4648 \\
\hline $\mathrm{N} 21-\mathrm{C} 22$ & $1.337(2)$ & 1.3353 & 1.3345 & 1.3158 & 1.3150 \\
\hline N21-C26 & $1.339(3)$ & 1.3331 & 1.3333 & 1.3154 & 1.3157 \\
\hline N24-C25 & $1.336(3)$ & 1.3349 & 1.3348 & 1.3163 & 1.3165 \\
\hline $\mathrm{N} 24-\mathrm{C} 23$ & $1.336(3)$ & 1.3328 & 1.3326 & 1.3168 & 1.3164 \\
\hline C1-C11 & $1.470(3)$ & 1.4651 & 1.4655 & 1.4784 & 1.4791 \\
\hline $\mathrm{C} 1-\mathrm{H} 1$ & 0.9500 & 1.0900 & 1.0899 & 1.0784 & 1.0786 \\
\hline $\mathrm{C} 2-\mathrm{C} 22$ & $1.512(3)$ & 1.5073 & 1.5079 & 1.5067 & 1.5078 \\
\hline C11-C16 & $1.397(3)$ & 1.4031 & 1.4035 & 1.3882 & 1.3886 \\
\hline C11-C12 & $1.402(3)$ & 1.4059 & 1.4060 & 1.3941 & 1.3945 \\
\hline C12-C13 & $1.381(3)$ & 1.3843 & 1.3849 & 1.3768 & 1.3775 \\
\hline C12-H12 & 0.9500 & 1.0819 & 1.0820 & 1.0721 & 1.0723 \\
\hline $\mathrm{C} 13-\mathrm{C} 14$ & $1.388(3)$ & 1.3941 & 1.3949 & 1.3852 & 1.3857 \\
\hline $\mathrm{C} 13-\mathrm{H} 13$ & 0.9500 & 1.0810 & 1.0813 & 1.0711 & 1.0715 \\
\hline C14-C15 & $1.388(3)$ & 1.3896 & 1.3903 & 1.3777 & 1.3779 \\
\hline $\mathrm{C} 15-\mathrm{C} 16$ & $1.389(3)$ & 1.3883 & 1.3888 & 1.3834 & 1.3843 \\
\hline C15-H15 & 0.9500 & 1.0808 & 1.0811 & 1.0710 & 1.0714 \\
\hline C16-H16 & 0.9500 & 1.0845 & 1.0846 & 1.0752 & 1.0754 \\
\hline $\mathrm{C} 22-\mathrm{C} 23$ & $1.391(3)$ & 1.3989 & 1.3986 & 1.3868 & 1.3872 \\
\hline C23-H23 & 0.9500 & 1.0845 & 1.0848 & 1.0736 & 1.0741 \\
\hline $\mathrm{C} 25-\mathrm{C} 26$ & $1.385(3)$ & 1.3945 & 1.3948 & 1.3860 & 1.3864 \\
\hline $\mathrm{C} 25-\mathrm{H} 25$ & 0.9500 & 1.0859 & 1.0857 & 1.0753 & 1.0753 \\
\hline $\mathrm{C} 26-\mathrm{H} 26$ & 0.9500 & 1.0859 & 1.0857 & 1.0751 & 1.0751 \\
\hline $\mathrm{C} 27-\mathrm{H} 27 \mathrm{~A}$ & 0.9800 & 1.0860 & 1.0863 & 1.0757 & 1.0761 \\
\hline $\mathrm{C} 27-\mathrm{H} 27 \mathrm{~B}$ & 0.9800 & 1.0939 & 1.0938 & 1.0861 & 1.0860 \\
\hline $\mathrm{C} 27-\mathrm{H} 27 \mathrm{C}$ & 0.9800 & 1.0934 & 1.0933 & 1.0847 & 1.0847 \\
\hline$R^{2}$ & & 0.9793 & 0.9799 & 0.9631 & 0.9633 \\
\hline
\end{tabular}

bond length is slightly longer than $\mathrm{C} 12-\mathrm{C} 13$. The longest bond distance observed in the benzene ring is $\mathrm{C} 11-\mathrm{C} 12$.

The experimental $\mathrm{C}-\mathrm{N}$ bond lengths fall in the range $1.278-1.470 \AA$ and the optimized $\mathrm{C}-\mathrm{N}$ bond lengths fall in the range $1.2835-1.4760 \AA$ by B3LYP $/ 6-311++\mathrm{G}(\mathrm{d}, \mathrm{p})$ method. From these values, a small difference between experimental and calculated bond lengths is observed.

The $\mathrm{C} 12-\mathrm{C} 13-\mathrm{C} 14$ and $\mathrm{C} 14-\mathrm{C} 15-\mathrm{C} 16$ ring angles are slightly smaller than $119^{\circ}$ at the point substitution and longer than $119^{\circ}$ at the other position, due to this reason the symmetry of the ring is slightly distorted. The rest of computed bond angles were correlated with the experimental values (see Table II). The highest correlation coefficient was obtained for DFT/B3LYP method with $6-311++\mathrm{G}(\mathrm{d}, \mathrm{p})$ basis set. In addition, this study concludes that the theoretically calculated dihedral angles are in good agreement with the experimental study [8]. 
TABLE II

The values of bond angles $\left({ }^{\circ}\right)$ calculated for the title compound using B3LYP and HF methods compared with experimental data $[8]$

\begin{tabular}{|c|c|c|c|c|c|}
\hline & \multirow{2}{*}{$\begin{array}{c}\text { Exp. [8] } \\
\quad A 1\end{array}$} & \multicolumn{2}{|c|}{ Calc. B3LYP } & \multicolumn{2}{|c|}{ Calc. HF } \\
\hline & & $A 2$ & $A 1$ & $A 2$ & \\
\hline C1-N1-N2 & 117.97(16) & 120.41 & 120.30 & 121.30 & 121.26 \\
\hline $\mathrm{C} 2-\mathrm{N} 2-\mathrm{N} 1$ & $116.92(15)$ & 117.71 & 117.35 & $\mid 117.30$ & 117.15 \\
\hline $\mathrm{C} 2-\mathrm{N} 2-\mathrm{C} 27$ & $120.87(15)$ & 119.09 & 119.51 & $\mid 119.82$ & 120.09 \\
\hline $\mathrm{N} 1-\mathrm{N} 2-\mathrm{C} 27$ & $122.20(15)$ & 123.01 & 123.01 & 122.35 & 122.34 \\
\hline O142-N14-O141 & $123.44(17)$ & 124.80 & 124.63 & $\mid 124.88$ & 124.79 \\
\hline O142-N14-C14 & $118.25(16)$ & 117.62 & 117.70 & 117.58 & 117.62 \\
\hline O141-N14-C14 & $118.30(16)$ & 117.58 & 117.67 & 117.55 & 117.59 \\
\hline C22-N21-C26 & $115.43(17)$ & 116.22 & 116.25 & 116.87 & 116.87 \\
\hline C25-N24-C23 & $115.58(17)$ & 116.20 & 116.36 & 116.81 & 116.90 \\
\hline N1-C1-C11 & $119.52(17)$ & 120.40 & 120.51 & 120.43 & 120.42 \\
\hline N1-C1-H1 & 120.2 & 123.18 & 123.08 & 123.43 & 123.41 \\
\hline C11-C1-H1 & 120.2 & 116.42 & 116.41 & 116.13 & 116.17 \\
\hline $\mathrm{O} 2-\mathrm{C} 2-\mathrm{N} 2$ & $121.95(17)$ & 121.59 & 121.85 & $\mid 121.92$ & 122.07 \\
\hline $\mathrm{O} 2-\mathrm{C} 2-\mathrm{C} 22$ & $119.60(17)$ & 119.89 & 120.17 & 119.40 & 119.54 \\
\hline $\mathrm{N} 2-\mathrm{C} 2-\mathrm{C} 22$ & $118.44(16)$ & 118.52 & 117.98 & 118.68 & 118.38 \\
\hline C16-C11-C12 & $119.38(17)$ & 119.04 & 119.01 & 119.40 & 119.40 \\
\hline C16-C11-C1 & $118.91(17)$ & 119.10 & 118.95 & 118.84 & 118.78 \\
\hline C12-C11-C1 & $121.66(17)$ & 121.87 & 122.04 & 121.76 & 121.82 \\
\hline C13-C12-C11 & $120.53(17)$ & 120.54 & 120.56 & 120.36 & 120.37 \\
\hline C13-C12-H12 & 119.7 & 120.57 & 120.38 & 120.24 & 120.14 \\
\hline C11-C12-H12 & 119.7 & 118.89 & 119.05 & 119.40 & 119.48 \\
\hline C12-C13-C14 & $118.41(18)$ & 119.02 & 119.01 & 118.94 & 118.91 \\
\hline C12-C13-H13 & 120.8 & 121.72 & 121.52 & 121.23 & 121.15 \\
\hline C14-C13-H13 & 120.8 & 119.26 & 119.47 & 119.83 & 119.95 \\
\hline C13-C14-C15 & $122.98(18)$ & 121.86 & 121.86 & 122.00 & 122.04 \\
\hline C13-C14-N14 & $118.50(17)$ & 119.12 & 119.12 & 119.03 & 119.00 \\
\hline C15-C14-N14 & $118.52(17)$ & 119.02 & 119.02 & 118.98 & 118.95 \\
\hline C14-C15-C16 & $117.64(17)$ & 118.61 & 118.58 & 118.48 & 118.44 \\
\hline C14-C15-H15 & 121.2 & 119.49 & 119.72 & 120.14 & 120.26 \\
\hline C16-C15-H15 & 121.2 & 121.91 & 121.69 & 121.39 & 121.30 \\
\hline C15-C16-C11 & $121.04(18)$ & 120.93 & 120.98 & 120.82 & 120.84 \\
\hline C15-C16-H16 & 119.5 & 119.38 & 119.33 & 119.15 & 119.12 \\
\hline C11-C16-H16 & 119.5 & 119.69 & 119.69 & 120.03 & 120.04 \\
\hline $\mathrm{N} 21-\mathrm{C} 22-\mathrm{C} 23$ & $122.45(17)$ & 121.77 & 121.86 & 121.67 & 121.74 \\
\hline $\mathrm{N} 21-\mathrm{C} 22-\mathrm{C} 2$ & $119.39(16)$ & 119.73 & 118.93 & 119.55 & 119.13 \\
\hline $\mathrm{C} 23-\mathrm{C} 22-\mathrm{C} 2$ & $117.89(16)$ & 118.17 & 118.91 & 118.53 & 118.89 \\
\hline N24-C23-C22 & $121.90(17)$ & 121.88 & 121.72 & 121.44 & 121.35 \\
\hline N24-C23-H23 & 119.0 & 117.60 & 117.56 & 117.82 & 117.84 \\
\hline C22-C23-H23 & 119.0 & 120.52 & 120.72 & 120.74 & 120.81 \\
\hline $\mathrm{N} 24-\mathrm{C} 25-\mathrm{C} 26$ & $122.57(19)$ & 121.93 & 121.86 & 121.68 & 121.63 \\
\hline N24-C25-H25 & 118.7 & 117.07 & 117.18 & 117.42 & 117.51 \\
\hline C26-C25-H25 & 118.7 & 121.00 & 120.96 & 120.90 & 120.86 \\
\hline N21-C26-C25 & $122.05(18)$ & 121.96 & 121.90 & 121.49 & 121.48 \\
\hline N21-C26-H26 & 119.0 & 116.97 & 117.06 & 117.41 & 117.48 \\
\hline C25-C26-H26 & 119.0 & 121.07 & 121.03 & & \\
\hline $\mathrm{N} 2-\mathrm{C} 27-\mathrm{H} 27 \mathrm{~A}$ & 109.5 & 107.31 & 107.54 & & \\
\hline N2-C27-H27B & 109.5 & 110.47 & 110.51 & & \\
\hline $\mathrm{H} 27 \mathrm{~A}-\mathrm{C} 27-\mathrm{H} 27 \mathrm{~B}$ & 109.5 & 109.42 & 109.35 & 109.12 & 109.12 \\
\hline $\mathrm{N} 2-\mathrm{C} 27-\mathrm{H} 27 \mathrm{C}$ & 109.5 & 110.30 & 110.19 & 110.26 & 110.20 \\
\hline $\mathrm{H} 27 \mathrm{~A}-\mathrm{C} 27-\mathrm{H} 27 \mathrm{C}$ & 109.5 & 109.92 & 109.76 & 109.41 & 109.33 \\
\hline $\mathrm{H} 27 \mathrm{~B}-\mathrm{C} 27-\mathrm{H} 27 \mathrm{C}$ & 109.5 & 109.40 & 109.46 & 109.38 & 109.43 \\
\hline$R^{2}$ & & 0.8963 & 0.9029 & 0.8964 & 0.8998 \\
\hline
\end{tabular}

TABLE III

The values of dihedral angles $\left({ }^{\circ}\right)$ calculated for the title compound using B3LYP and HF methods compared with experimental data [8]

\begin{tabular}{l|c|c|c|c|c}
\hline \hline & Exp. [8] & \multicolumn{2}{|c|}{ Calc. } & B3LYP & \multicolumn{2}{|c}{ Calc. HF } \\
\cline { 3 - 6 } & $A 1$ & $A 2$ & $A 1$ & $A 2$ & \\
\hline C1-N1-N2-C2 & $178.94(16)$ & 178.79 & 178.74 & 177.18 & 177.39 \\
C1-N1-N2-C27 & -0.1 & 3.94 & -3.05 & 5.55 & -4.77 \\
N2-N1-C1-C11 & -175.23 & -179.75 & -179.61 & 179.85 & -179.72 \\
N1-N2-C2-O2 & $178.58(16)$ & -167.45 & 168.47 & 164.70 & 165.92 \\
C27-N2-C2-O2 & -2.4 & 7.61 & -7.38 & 7.15 & -6.88 \\
N1-N2-C2-C22 & -0.8 & 13.25 & -12.34 & 16.21 & -14.93 \\
C27-N2-C2-C22 & $178.22(15)$ & -171.68 & 171.82 & 171.94 & 172.27 \\
N1-C1-C11-C16 & -179.05 & 178.07 & -178.16 & 177.61 & -177.27 \\
N1-C1-C11-C12 & $3.5(3)$ & -2.06 & 1.90 & 2.50 & 2.81 \\
C16-C11-C12-C13 & -1.3 & -0.11 & -0.13 & 0.11 & -0.16 \\
C1-C11-C12-C13 & $176.12(17)$ & -179.99 & 179.93 & 180.00 & 179.92 \\
C11-C12-C13-C14 & $0.6(3)$ & -0.00 & 0.04 & 0.02 & 0.08 \\
C12-C13-C14-C15 & $1.0(3)$ & 0.10 & 0.07 & 0.05 & 0.02 \\
C12-C13-C14-N14 & -178.83 & 179.98 & -179.97 & 179.96 & -179.95 \\
O142-N14-C14-C13 & -173.56 & 179.90 & -179.89 & 179.82 & -179.83 \\
O141-N14-C14-C13 & $6.8(3)$ & -0.10 & 0.11 & 0.19 & 0.18 \\
O142-N14-C14-C15 & $6.6(3)$ & -0.23 & 0.20 & 0.27 & 0.24 \\
O141-N14-C14-C15 & -173.05 & 179.78 & -179.80 & 179.72 & -179.75 \\
C13-C14-C15-C16 & -1.8 & -0.08 & -0.07 & 0.04 & -0.03 \\
N14-C14-C15-C16 & $178.07(16)$ & -179.95 & 179.97 & 179.95 & 179.96 \\
C14-C15-C16-C11 & $1.0(3)$ & -0.04 & 0.04 & 0.05 & 0.05 \\
C12-C11-C16-C15 & $0.5(3)$ & 0.14 & 0.13 & 0.12 & 0.14 \\
C1-C11-C16-C15 & -176.98 & -179.99 & -179.93 & 179.98 & -179.94 \\
C26-N21-C22-C23 & -0.8 & 0.64 & -0.39 & 0.42 & -0.24 \\
C26-N21-C22-C2 & -174.73 & 174.01 & -174.04 & 174.55 & -174.59 \\
O2-C2-C22-N21 & $118.3(2)$ & -130.59 & 122.81 & 130.07 & 125.14 \\
N2-C2-C22-N21 & -62.3 & 48.72 & -56.40 & 49.04 & -54.04 \\
O2-C2-C22-C23 & -55.9 & 43.01 & -51.03 & 44.24 & -49.38 \\
N2-C2-C22-C23 & $123.49(19)$ & -137.68 & 129.76 & 136.65 & 131.45 \\
C25-N24-C23-C22 & -0.4 & 1.95 & -1.86 & 1.81 & -1.77 \\
N21-C22-C23-N24 & $0.9(3)$ & -2.34 & 2.06 & 1.97 & 1.81 \\
C2-C22-C23-N24 & $174.98(18)$ & -175.81 & 175.71 & 176.15 & 176.18 \\
C23-N24-C25-C26 & -0.3 & -0.08 & -0.20 & 0.29 & -0.34 \\
C22-N21-C26-C25 & $0.2(3)$ & 1.22 & 1.28 & 1.10 & 1.20 \\
N24-C25-C26-N21 & $0.4(4)$ & -1.58 & 1.44 & 1.23 & 1.21 \\
\hline$R^{2}$ & & 0.9972 & 0.9986 & 0.9970 & 0.9981 \\
& & & &
\end{tabular}

\section{2. $N M R$ spectral analysis}

Geometrical structures of studied compound were optimized by HF and DFT/B3LYP methods and the gaugeindependent atomic orbital (GIAO) [31], the continuous set of gauge transformations (CSGT) [32] and the individual gauges for atoms in molecules (IGAIM, a slight variation on the CSGT method) [33] methods were used for prediction of nuclear shielding.

Theoretical and experimental chemical shifts of the title molecule in ${ }^{1} \mathrm{H}$ and ${ }^{13} \mathrm{C}$ NMR spectra in comparison with experimental chemical shifts are gathered in Table IV. The linear correlation between proton and carbon NMR shieldings of studied compound and experimental data is shown in Table IV. This data show good 
TABLE IV

Experimental [8] and theoretical B3LYP and HF with $6-311++\mathrm{G}(\mathrm{d}, \mathrm{p})$ chemical shifts $\delta$ [ppm] of the title compound in ${ }^{1} \mathrm{H}$ and ${ }^{13} \mathrm{C}$ NMR spectra

\begin{tabular}{|c|c|c|c|c|c|c|c|}
\hline & \multirow[t]{2}{*}{ Exp. [8] } & \multicolumn{3}{|c|}{ Calc. B3LYP } & \multicolumn{3}{|c|}{ Calc. HF } \\
\hline & & GIAO & CSGT & IGAIM & GIAO & CSGT & IGAIM \\
\hline \multicolumn{8}{|c|}{${ }^{1} \mathrm{H}$ NMR $\left(\mathrm{CDCl}_{3}\right)$} \\
\hline H3 & 8.85 & 9.02 & 9.83 & 9.12 & 9.43 & 9.46 & 9.46 \\
\hline $\mathrm{H} 5$ & 8.70 & 8.76 & 9.58 & 8.86 & 9.15 & 9.23 & 9.22 \\
\hline H6 & 8.70 & 8.66 & 9.47 & 8.75 & 8.96 & 9.08 & 9.08 \\
\hline $\mathrm{H} 3^{\prime}$ & 8.17 & 8.20 & 8.79 & 8.07 & 8.84 & 8.67 & 8.67 \\
\hline $\mathrm{H} 5^{\prime}$ & 8.17 & 8.42 & 8.93 & 8.21 & 9.05 & 8.84 & 8.84 \\
\hline $\mathrm{N}=\mathrm{CH}$ & 7.84 & 7.53 & 8.60 & 7.88 & 7.69 & 7.99 & 7.99 \\
\hline $\mathrm{H} 2^{\prime}$ & 7.52 & 7.66 & 8.54 & 7.83 & 8.02 & 8.19 & 8.19 \\
\hline $\mathrm{H} 6^{\prime}$ & 7.52 & 7.30 & 8.22 & 7.50 & 7.72 & 7.91 & 7.91 \\
\hline $\mathrm{NCH}_{3}$ & 3.64 & 5.14 & 5.98 & 5.26 & 5.04 & 5.26 & 5.26 \\
\hline $\mathrm{NCH}_{3}$ & 3.64 & 2.72 & 3.98 & 3.27 & 2.92 & 3.48 & 3.48 \\
\hline $\mathrm{NCH}_{3}$ & 3.64 & 2.56 & 3.82 & 3.10 & 2.69 & 3.24 & 3.24 \\
\hline$R^{2}$ & & 0.9205 & 0.9360 & 0.9361 & 0.9357 & 0.9496 & 0.9496 \\
\hline \multicolumn{8}{|c|}{${ }^{13} \mathrm{C}$ NMR } \\
\hline $\mathrm{C} 2$ & 167.7 & 174.2 & 172.6 & 172.6 & 178.6 & 177.7 & 177.7 \\
\hline $\mathrm{C} 22$ & 149.8 & 157.4 & 155.1 & 155.0 & 160.9 & 158.6 & 158.6 \\
\hline $\mathrm{C} 23$ & 148.4 & 151.6 & 149.1 & 149.1 & 156.0 & 153.6 & 153.6 \\
\hline $\mathrm{C} 25$ & 145.2 & 150.5 & 148.6 & 148.6 & 155.4 & 153.7 & 153.7 \\
\hline C14 & 144.8 & 154.4 & 151.5 & 151.5 & 154.7 & 152.2 & 152.2 \\
\hline C11 & 143.8 & 147.0 & 146.6 & 146.6 & 154.3 & 153.8 & 153.8 \\
\hline $\mathrm{C} 26$ & 139.9 & 147.6 & 145.5 & 145.5 & 150.6 & 149.2 & 149.2 \\
\hline $\mathrm{C} 1$ & 138.1 & 137.9 & 137.6 & 137.6 & 141.9 & 142.0 & 142.0 \\
\hline $\mathrm{C} 15$ & 128.8 & 129.3 & 126.9 & 126.9 & 138.0 & 135.7 & 135.7 \\
\hline $\mathrm{C} 13$ & 128.8 & 129.3 & 127.0 & 127.0 & 137.8 & 135.6 & 135.6 \\
\hline $\mathrm{C} 16$ & 127.8 & 133.0 & 132.7 & 132.7 & 136.9 & 136.4 & 136.3 \\
\hline $\mathrm{C} 12$ & 124.2 & 128.8 & 127.4 & 127.4 & 133.9 & 132.6 & 132.6 \\
\hline $\mathrm{C} 27$ & 28.9 & 27.1 & 27.7 & 27.7 & 31.2 & 32.1 & 32.1 \\
\hline$R^{2}$ & & 0.9939 & 0.9940 & 0.9940 & 0.9972 & 0.9975 & 0.9975 \\
\hline
\end{tabular}

correlation between predicted and observed proton and carbon chemical shifts but the higher value of correlation coefficient was obtained by HF (CSGT and IGAIM) method (see supplementary information). The results are based on fixed geometry and a rigid conformation. Aromatic carbon atoms in benzene ring give signals in overlapped areas of the spectrum with chemical shift values from 120 to $160 \mathrm{ppm}$. The cumulative effect of nitrogen and oxygen reduce the electron density of the carbon atom C2, thus its NMR signal is observed in the very downfield at $167.7 \mathrm{ppm}$ experimentally. This signal calculated in the range $172.6-178.6 \mathrm{ppm} .{ }^{1} \mathrm{H}$ chemical shifts were obtained by complete analysis of the NMR spectrum and interpreted critically to quantify different effects acting on the chemical shifts of protons. The hydrogen atoms in the benzene ring shows NMR peaks in the normal range of aromatic hydrogen atoms and are assigned to the chemical shift values 8.17 (H3', H5') and 7.52 (H2' and $\mathrm{H} 6$ ') ppm. The computed chemical shift values of 8.20-9.05 (H3', H5') and 7.30-8.54 (H2' and H6') ppm for proton atoms are in good agreement with the measured values (8.17 and $7.52 \mathrm{ppm})$.

\subsection{Frontier molecular orbital analysis}

The energies of four important molecular orbitals of the title molecule: the second highest and highest occupied MO's (HOMO and HOMO-1), the lowest and the second lowest unoccupied MO's (LUMO and LUMO+1) were calculated and are presented in Fig. 2 with the 3D plots. The energy gap of the title molecule was calculated at B3LYP $/ 6-311++\mathrm{G}(\mathrm{d}, \mathrm{p})$ level, which reveals the chemical reactivity and proves the occurrence of eventual charge transfer.

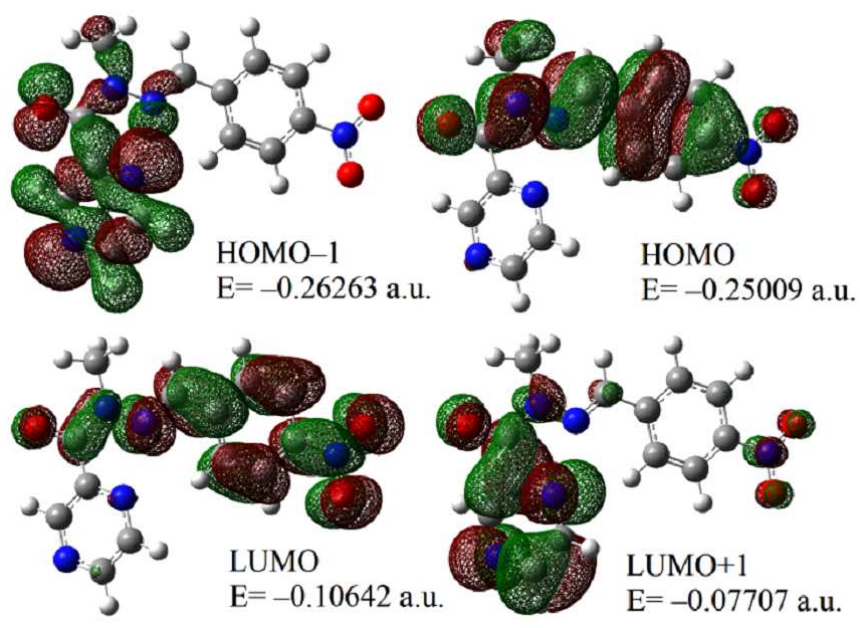

Fig. 2. The atomic orbital composition of the frontier molecular orbital of the title compound obtained by B3LYP $/ 6-311++\mathrm{G}(\mathrm{d}, \mathrm{p})$ level.

The HOMO (ability to donate an electron) is located almost over the carbon atoms, oxygen atoms and also slightly delocalized in hydrogen atom and the LUMO (ability to obtain an electron) is mainly delocalized in carbon atoms of benzene ring and nitro group.

The energy gap (energy difference between HOMO and LUMO orbital) is a critical parameter in determining molecular electrical transport properties [34]. The HOMO-LUMO energy gap of the title molecule is found to be 0.14367 a.u. obtained at DFT/B3LYP method with $6-311++\mathrm{G}(\mathrm{d}, \mathrm{p})$ level. The energy gap also determines the chemical hardness softness of a molecule. By using the energies of the HOMO and LUMO orbitals, absolute hardness value of a molecule can be formulated by the equation: $\eta=(1 / 2)\left(-\varepsilon_{\mathrm{HOMO}}+\varepsilon_{\mathrm{LUMO}}\right)[35-$ 37 . The value of hardness is $0.071835 \mathrm{a} . \mathrm{u}$. for the title molecule. Molecules having a large energy gap are known as hard and having a small energy gap are known as soft molecules. Soft molecules are more polarizable than hard molecules because they need small excitation energies to the manifold of excited states [38].

\subsection{Potential energy surface scan}

Visualizing and describing the relationship between potential energy and molecular geometry is called a potential energy surface (PES) that is an important to reveal 
all possible conformations of the title molecule. The scan studies were obtained by minimizing the potential energy in all geometrical parameters by varying the torsion angle at a step of $10^{\circ}$ in the range of $0-360^{\circ}$ rotation around the bond. For the calculation, all the geometrical parameters were synchronically relaxed while the $\mathrm{C} 1-\mathrm{N} 1-\mathrm{N} 2-$ $\mathrm{C} 2$ angle was varied in steps of $10^{\circ}$. The $2 \mathrm{D}$ surface in a 3D diagram and 2D surface countour graph of a PES scan performed for the dihedral angles $\mathrm{C} 1-\mathrm{N} 1-\mathrm{N} 2-\mathrm{C} 2$, $\mathrm{N} 2-\mathrm{C} 2-\mathrm{C} 22-\mathrm{C} 23$ and $\mathrm{C} 1-\mathrm{N} 1-\mathrm{N} 2-\mathrm{C} 2, \mathrm{~N} 1-\mathrm{C} 1-\mathrm{C} 11-\mathrm{C} 16$ at the B3LYP $/ 6-311 \mathrm{G}(\mathrm{d}, \mathrm{p})$ level of theory for the title molecule is shown in Fig. 3 and Fig. 4.
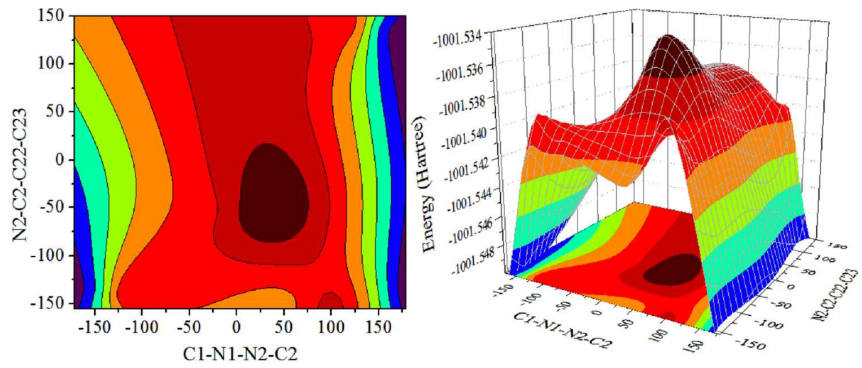

Fig. 3. PES reaction surface plot of $\mathrm{C} 1-\mathrm{N} 1-\mathrm{N} 2-\mathrm{C} 2$ and $\mathrm{N} 2-\mathrm{C} 2-\mathrm{C} 22-\mathrm{C} 23$ of the title compound obtained by B3LYP/6-311G(d,p) level.
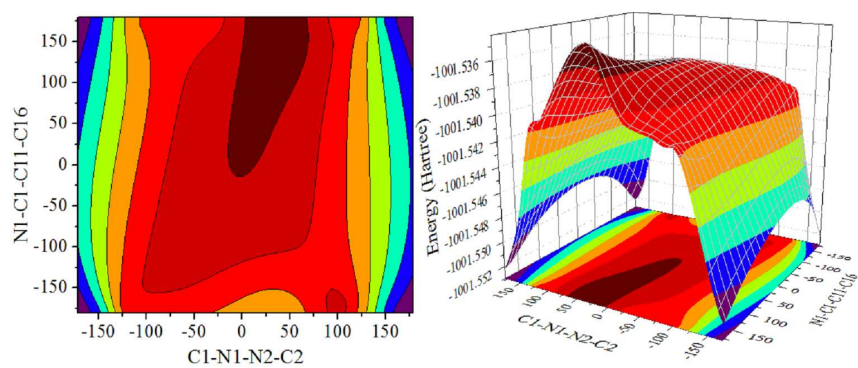

Fig. 4. PES reaction surface plot of $\mathrm{C} 1-\mathrm{N} 1-\mathrm{N} 2-\mathrm{C} 2$ and N1-C1-C11-C16 of the title compound obtained by B3LYP/6-311G(d,p) level.

The PES scan revealed that the $\mathrm{C} 1-\mathrm{N} 1-\mathrm{N} 2-\mathrm{C} 2$ dihedral angle has two energetically almost equal minimum energy at $179^{\circ}$ with the energy of -1001.5521947200 and $-1001.5521698000 \mathrm{Ha}$ at a combination of $\mathrm{N} 2-\mathrm{C} 2-\mathrm{C} 22-$ $\mathrm{C} 23$ dihedral angle of $-138^{\circ}$ and $137^{\circ}$ and $\mathrm{N} 1-\mathrm{C} 1-\mathrm{C} 11-$ C16 dihedral of $-178^{\circ}$ and $178^{\circ}$.

\subsection{NPA and Mulliken atomic charges}

The Mulliken analysis is the most popular population analysis method, it is by default always performed in Gaussian. The first involve a direct partitioning of the molecular wave function into atomic contributions following some arbitrary, orbital-based scheme proposed by Mulliken [39]. The Mulliken population analysis is one of the oldest and simplest, with the electrons being divided up amongst the atoms according to the degree to which different atomic AO basis functions contribute to the overall wave function [39]. The Mulliken charges do not achieve convergence with an increasing basis set size. Natural population analysis (NPA) and Mulliken methods predict the same tendencies.

The atomic charges of the title molecule acquired by the Mulliken population analysis and NPA with HF and B3LYP methods with $6-311 \mathrm{G}(\mathrm{d}, \mathrm{p})$ and $6-311++\mathrm{G}(\mathrm{d}, \mathrm{p})$ basis sets are listed in Table V. The Mulliken and NPA atomic charges on each atom of the title compound are presented in the graphical representation shown in Fig. 5 and Fig. 6, respectively.

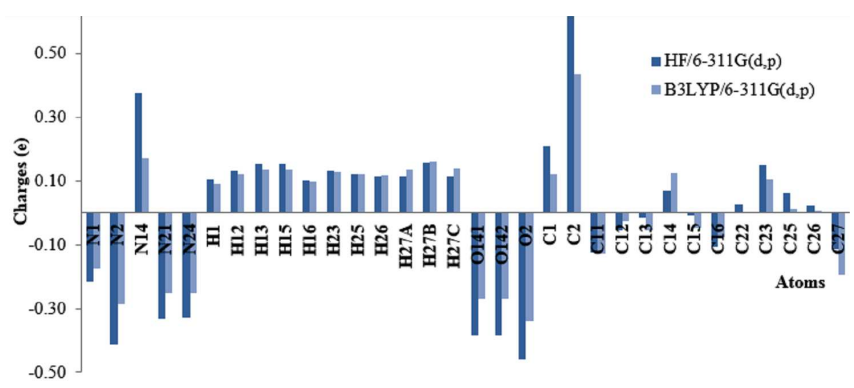

Fig. 5. Comparative Mulliken plot of the title compound obtained by HF and B3LYP methods with 6$311 \mathrm{G}(\mathrm{d}, \mathrm{p})$ basis set.

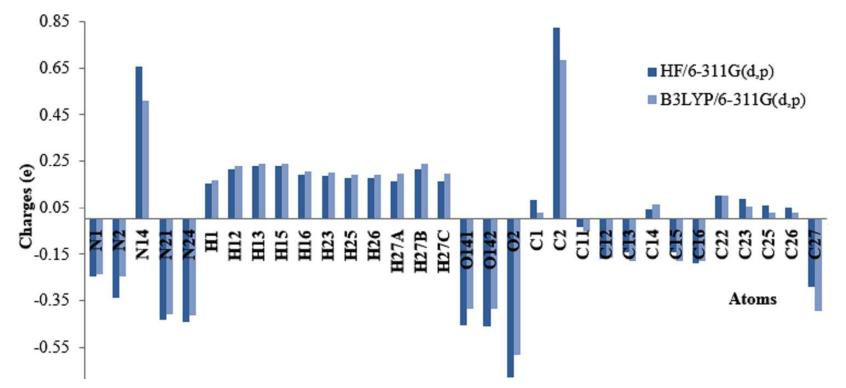

Fig. 6. Comparative NPA plot of the title compound obtained by HF and B3LYP methods with 6-311G(d,p) basis set.

From the results it is clear that carbon atoms attached with oxygen and nitrogen atoms are positive however the other carbon atoms have more negative charges. All hydrogen atoms have a positive charge and the oxygen and nitrogen atoms are negatively charged. The H13 and H15 atoms have positive and maximum atomic charges than the other hydrogen atoms. Due to the presence of electronegative oxygen atoms in the nitro group, nitrogen atom has large positive charge value N14. The methyl group nitrogen atom $\mathrm{N} 2$ has the maximum negative charge value compared to other nitrogen atoms of the nitro group N1, N21 and N24. 


\section{TABLE $\mathrm{V}$}

Calculated net charges by the Mulliken population analysis and NPA analysis of the title compound at B3LYP and HF methods with $A 1$ and $A 2$ basis sets

\begin{tabular}{|c|c|c|c|c|c|c|c|c|}
\hline & \multicolumn{2}{|c|}{ Mulliken B3LYP } & \multicolumn{2}{|c|}{ NPA B3LYP } & \multicolumn{2}{|c|}{ Mulliken HF } & \multicolumn{2}{|c|}{ NPA HF } \\
\hline & $A 1$ & $A 2$ & $A 1$ & $A 2$ & $A 1$ & $A 2$ & $A 1$ & $A 2$ \\
\hline IVI & .17334 & 0.143948 & 23435 & -0.22274 & -0.214765 & 0.2200 & .24207 & -0.24 \\
\hline & & & & & & & & \\
\hline & & -05 & 253 & & 4672 & & & \\
\hline & 1772 & 16 & 0773 & 48 & & & 2992 & -0.42992 \\
\hline & & 21276 & 1098 & & & & & \\
\hline & 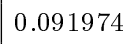 & 0 & 00 & 5 & 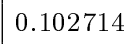 & 0.100 & 29 & 0.15529 \\
\hline & 20445 & 84 & 2702 & 97 & & 4 & 54 & 54 \\
\hline & 7 & 7 & 8 & 8 & 7 & 33 & 30 & 90 \\
\hline & & & & & & & & \\
\hline & & & & & & & & \\
\hline & 29040 & 1291 & 9920 & & & & 104 & \\
\hline & 22332 & 202844 & 9023 & 20223 & 22813 & 3 & 63 & 0. \\
\hline 126 & 16632 & 0.210304 & 9061 & 20119 & 16204 & 88 & 7629 & 0.17629 \\
\hline $27 \Delta$ & 47 & 14 & 4 & 61 & 3 & 3 & 48 & 10 \\
\hline & & & & & & & & \\
\hline & & & & & & & & \\
\hline & & & 994 & & & & 76 & \\
\hline 142 & -0.26977 & -0.003741 & 3556 & 38002 & 43 & & 911 & -0 \\
\hline 2 & -0.33721 & -0.223964 & 58049 & -0.57941 & 57382 & 68 & 7880 & -0.67 \\
\hline 1 & 0.122074 & -0.307487 & 02984 & 0.03017 & 09706 & 49 & 3229 & 29 \\
\hline $\mathrm{C} 2$ & & 7502 & 3295 & & & & 2584 & 0.82584 \\
\hline & & & & & & & & 0.06 \\
\hline & & & & & & & & \\
\hline & & 9246 & 7664 & -0 & 15135 & -0 & 4180 & -0 \\
\hline & & & & & & & & \\
\hline & .047309 & -0.246248 & .17722 & & -0.00983 & & & \\
\hline & & -0.518585 & .18075 & -0.18320 & -0.105093 & & -0.18741 & -0.18741 \\
\hline $\mathrm{C} 22$ & & 0.052263 & 0.10319 & & & & .10306 & \\
\hline & & & & & & & & \\
\hline & & & & & & & & \\
\hline & & & 0.0 & & 0.02334 & & 0.04965 & 0.04965 \\
\hline $\mathrm{C} 27$ & -0.193511 & -0.300654 & -0.39481 & -0.41050 & -0.112748 & -0.293565 & -0.29125 & -0.29125 \\
\hline
\end{tabular}

\section{6. $N B O$ analysis}

The importance of the NBO method is originated from that it gives information about intra- and intermolecular bonding and interactions among bonds. Furthermore, it provides a convenient basis for investigating the interactions in both filled and virtual orbital spaces along with charge transfer and conjugative interactions in molecular system. The second-order Fock matrix was used to evaluate the donor acceptor interactions in the NBO basis [39]. The interactions result in a loss of occupancy from the localized NBO of the idealized Lewis structure into an empty non-Lewis orbital. For each donor $(i)$ and acceptor $(j)$, the stabilization energy $\mathrm{E}(2)$ associated with the delocalization $i \rightarrow j$ is estimated as [40]:

$$
E(2)=\Delta E_{i \rightarrow j}=q_{i} \frac{F(i, j)^{2}}{\left(\varepsilon_{j}-\varepsilon_{i}\right)},
$$

where $q_{i}$ is the donor orbital occupancy, $\varepsilon_{i}$ and $\varepsilon_{j}$ are the diagonal elements (orbital energies) and $F(i, j)$ is the off diagonal NBO Fock matrix element. The larger the $E(2)$ value, the more intensive is the interaction between elec- tron donors and electron acceptors, i.e. the more donating tendency from electron donors to electron acceptors and the greater the extent of conjugation of the whole system [41].

NBO analysis has been performed on the molecule at the HF and DFT/B3LYP methods with $6-311++\mathrm{G}(\mathrm{d}, \mathrm{p})$ level in order to elucidate the possible donor-acceptor pairs, the values of the donor-acceptor stabilization energy as estimated by the above equation and NBO occupancies that are presented in Table VI. Tables also include the corresponding Fock matrix elements in the numerator and denominator of this equation.

The $\pi$ electron delocalization is maximum around C23-N24, C25-C26 distributed to $\pi^{*}$ antibonding of C25-C26, N21-C22 with a stabilization energy of about $50.03,49.11 \mathrm{kcal} / \mathrm{mol}$ for $\mathrm{HF} / 6-311++\mathrm{G}(\mathrm{d}, \mathrm{p})$ and 24.42 , $20.35 \mathrm{kcal} / \mathrm{mol}$ for B3LYP $/ 6-311++\mathrm{G}(\mathrm{d}, \mathrm{p})$. NBO analysis clearly manifests the evidences of the intramolecular charge transfer from $\sigma(\mathrm{C} 27-\mathrm{H} 27 \mathrm{~A})$ to $\sigma^{*}(\mathrm{~N} 1-\mathrm{N} 2)$ antibonding orbitals that clearly shows that the hy- 
droxyl group is inclined towards the $\mathrm{C}_{2} 7 \mathrm{H}_{3}$ group showing large stabilization energy of $6.94 \mathrm{kcal} / \mathrm{mol}$ $(\mathrm{HF} / 6-311++\mathrm{G}(\mathrm{d}, \mathrm{p})$ and $5.69 \mathrm{kcal} / \mathrm{mol}$ (B3LYP $/ 6-$ $311++\mathrm{G}(\mathrm{d}, \mathrm{p})$. The most important interaction energies in this molecule are $\sigma$ electron donating from $\mathrm{LP}(1) \mathrm{O} 141 \rightarrow \sigma^{*}(\mathrm{C} 14-\mathrm{N} 14)$ and $\mathrm{LP}(1) \mathrm{O} 141 \rightarrow$ $\sigma^{*}(\mathrm{C} 14-\mathrm{N} 14)$ resulting a stabilization energy of about $5.74,4.20 \mathrm{~kJ} / \mathrm{mol}$ respectively. In title molecule, the interaction of lone pair orbital on oxygen atom LP (3) O142 LP (3) O142 of the NBO conjugated with $\pi^{*}(\mathrm{~N} 14-\mathrm{O} 141)$ resulting to stabilization of $283.13 \mathrm{kcal} / \mathrm{mol}(\mathrm{HF})$ and $163.10 \mathrm{kcal} / \mathrm{mol}$ (B3LYP) shown in Table VI(at the end). Percentage of $s, p$, and $d$-character on each natural atomic hybrid of the natural bond orbital is listed in Table VII (at the end).

As shown in Table VI, the difference in polarization coefficients is small when similar atoms are involved in bond formation $(\mathrm{C}-\mathrm{C}, \mathrm{N}-\mathrm{N}$ bond) however in $\mathrm{C}-\mathrm{N}$ and $\mathrm{C}-\mathrm{O}$ bond formations there are found considerable differences. The sizes of the polarization coefficients of the corresponding bond provides information about the electronegativity, the larger differences in the polarization coefficient values of the atoms involved in the bond formation are reflected in the electronegativity of the atoms.

\section{Conclusion}

The geometry of methylated pyrazine-2carbohydrazide derivative, namely $N$-methyl- $N^{\prime}-(4-$ nitrobenzylidene)pyrazine-2-carbohydrazide was optimized at different levels with HF and DFT/B3LYP method using 6-311G(d,p) and 6-311++G(d,p). The computed geometries are benchmarks for predicting crystal structural data of the molecule. The calculated structural parameters (bond distances, bond angles and dihedral angles) compares well with the experimental values. The ${ }^{1} \mathrm{H}$ and ${ }^{13} \mathrm{C}$ NMR isotropic chemical shifts were calculated and the assignments made were compared with the experimental values. HOMO-LUMO gaps are examined and discussed. The potential energy curves have been obtained for C2-N2-N1-C1 and $\mathrm{N} 1-\mathrm{C} 1-\mathrm{C} 11-\mathrm{C} 16$ rotational angles at the same levels of theory. The NBO analysis revealed that the $\mathrm{LP}(3) \mathrm{O} 2 \rightarrow \mathrm{LP}^{*}$ (1) C2 interaction gives the strongest stabilization to the system around at $416.19 \mathrm{kcal} / \mathrm{mol}$ with $\mathrm{HF} / 6-311++\mathrm{G}(\mathrm{d}, \mathrm{p})$.

\section{References}

[1] A.K. Singh, P. Kumar, M. Yadav, D.S. Pandey, J. Organomet. Chem. 695, 567 (2010).

[2] X.H. Zhao, S.S. Liu, Y.Z. Li, M.D. Chen, Spectrochim. Acta A 75, 794 (2010).

[3] T. Asaki, T. Hamamoto, Y. Sugiyama, K. Kuwano, K. Kuwabara, Bioorgan. Med. Chem. 15, 6692 (2007).

[4] J.W. Corbett, M.R. Rauckhorst, F. Qian, R.L. Hoffman, C.S. Knauer, L.W. Fitzgerald, Bioorgan. Med. Chem. 17, 6250 (2007).
[5] H. Endredi, F. Billes, F.S. Holly, J. Mol. Struct. 633, 73 (2003)

[6] S.R. Pattan, P.A. Rabara, J.S. Pattan, A.A. Bukitagar, V.S. Wakale, D.S. Musmade, Indian J. Chem. 48, 1453 (2009).

[7] D. Sriram, P. Yogeeswari, S.P. Reddy, Bioorgan Med. Chem. Lett. 16, 2113 (2006).

[8] L.R. Gomes, J.N. Low, A.S.M.C. Rodrigues, J.L. Wardell, C.H. Lima, M.V.N. de Souza, Acta Crystallogr. C 69, 549 (2013).

[9] S.M. Sondhi, M. Dinodia, A. Kumar, Eur J. Med. Chem. 44, 1010 (2009).

[10] A. Tanitame, Y. Oyamada, K. Ofuji, H. Terauchi, M. Kawasaki, M. Wachi, J.-I. Yamagishi, Bioorgan. Med. Chem. Lett. 15, 4299 (2005).

[11] I. Koca, A. Özgür, K.A. Coşkun, Y. Tutar, Bioorgan. Med. Chem. 21, 3859 (2013).

[12] S. Tyagarajan, P.K. Chakravarty, B. Zhou, B. Taylor, R. Eid, M.H. Fisher, W.H. Parsons, M.J. Wyvratt, K.A. Lyons, T. Klatt, X. Li, S. Kumar, B. Williams, J. Felix, B.T. Priest, R.M. Brochu, V. Warren, M. Smith, M. Garcia, G.J. Kaczorowski, W.J. Martin, C. Abbadie, E. McGowan, N. Jochnowitz, A. Weber, J.L. Duffy, Bioorgan. Med. Chem. Lett. 20, 7479 (2010).

[13] S.-R. Shih, T.-Y. Chu, G. Reddy, S.-N. Tseng, H.L. Chen, W.-F. Tang, M.-S. Wu, J.-Y. Yeh, Y.S. Chao, J.T.A. Hsu, H.-P. Hsieh, J.-T. Horng, J. Biomed. Sci. 17, 13 (2010).

[14] H.Y. Lo, C.C. Man, R.W. Fleck, N.A. Farrow, R.H. Ingraham, A. Kukulka, J.R. Proudfoot, R. Betageri, T. Kirrane, U. Patel, R. Sharma, M.A. Hoermann, A. Kabcenell, S. de Lombaert, Bioorgan. Med. Chem. Lett. 26, 6379 (2010).

[15] R. Kasimoğullari, M. Bülbül, B.S. Arslan, B. Gökçe, Eur. J. Med. Chem. 45, 4769 (2010).

[16] A. Padmaja, C. Rajasekhar, A. Muralikrishna, V. Padmavathi, Eur. J. Med. Chem. 46, 5034 (2011).

[17] N. Gökhan-Kelekçi, S. Koyunoglu, S. Yabanoglu, K. Yelekçi, Ö. Özgen, G. Uçar, K. Erol, E. Kendi, A. Yeşilada, Bioorgan. Med. Chem. 17, 675 (2009).

[18] D.M. Shen, E.J. Brady, M.R. Candelore, Q. DallasYang, V.D.-H. Ding, W.P. Feeney, G. Jiang, M.E. McCann, S. Mock, S.A. Qureshi, R. Saperstein, X. Shen, X. Tong, L.M. Tota, M.J. Wright, X. Yang, S. Zheng, K.T. Chapman, B.B. Zhang, J.R. Tata, E.R. Parmee, Bioorgan. Med. Chem. Lett. 21, 76 (2011).

[19] K. Gobis, H. Foks, Z. Zwolska, E. AugustynowiczKopeć, Heterocycles 81, 917 (2010).

[20] S.M.S.V. Wardell, M.V.N. de Souza, J.L. Wardell, J.N. Low, C. Glidewell, Acta Crystallogr. E 62, 3765 (2006).

[21] M. Yoshida, T. Shimada, T. Ishida, T. Kogane, Polyhedron 66, 75 (2013).

[22] B. Milczarska, K. Gobis, H. Foks, L. Golunski, P. Sowinski, J. Heterocyclic Chem. 49, 845 (2012).

[23] A.D. Becke, J. Chem. Phys. 98, 5648 (1993).

[24] C. Lee, W. Yang, R.G. Parr, Phys. Rev. B 37, 785 (1988). 
[25] M.J. Frisch, G.W. Trucks, H.B. Schlegel, G.E. Scuseria, M.A. Robb, J.R. Cheeseman, G. Scalmani, V. Barone, B. Mennucci, G.A. Petersson, H. Nakatsuji, M. Caricato, X. Li, H.P. Hratchian, A.F. Izmaylov, J. Bloino, G. Zheng, J.L. Sonnenberg, M. Hada, M. Ehara, K. Toyota, R. Fukuda, J. Hasegawa, M. Ishida, T. Nakajima, Y. Honda, O. Kitao, H. Nakai, T. Vreven, J.A. Montgomery Jr., J.E. Peralta, F. Ogliaro, M. Bearpark, J.J. Heyd, E. Brothers, K.N. Kudin, V.N. Staroverov, R. Kobayashi, J. Normand, K. Raghavachari, A. Rendell, J.C. Burant, S.S. Iyengar, J. Tomasi, M. Cossi, N. Rega, J.M. Millam, M. Klene, J.E. Knox, J.B. Cross, V. Bakken, C. Adamo, J. Jaramillo, R. Gomperts, R.E. Stratmann, O. Yazyev, A.J. Austin, R. Cammi, C. Pomelli, J.W. Ochterski, R.L. Martin, K. Morokuma, V.G. Zakrzewski, G.A. Voth, P. Salvador, J.J. Dannenberg, S. Dapprich, A.D. Daniels, Ö. Farkas, J.B. Foresman, J.V. Ortiz, J. Cioslowski, D.J. Fox, Gaussian 09, Revision A.1, Gaussian Inc., Wallingford CT, 2009.

[26] R. Dennington, T. Keith, J. Millam, Semichem Inc., Shawnee Mission KS, GaussView, Version 5, 2009.

[27] E.D. Glendening, A.E. Reed, J.E. Carpenter, F. Weinhold, NBO version 3.1.

[28] H. Pir, N. Gunay, Ö. Tamer, D. Avci, E. Tarcan, Y. Atalay, Mater. Sci.-Poland 31, 357 (2013).

[29] Ö. Tamer, D. Avci, Y. Atalay, Spectrochim. Acta A 117, 78 (2014).
[30] A. Kunduracioğlu, Ö. Tamer, D. Avci, İ. Kani, Y. Atalay, B. Çetinkaya, Spectrochim. Acta A 121, 35 (2014).

[31] R. Ditchfield, J. 'Chem. Phys. 56, 5688 (1972).

[32] T.A. Keith, R.F.W. Bader, Chem. Phys. Lett. 210, 223 (1993).

[33] T.A. Keith, R.F.W. Bader, Chem. Phys. Lett. 194, 1 (1992).

[34] K. Fukui, Science 218, 747 (1982).

[35] R.G. Parr, R.G. Pearson, J. Am. Chem. Soc. 105, 7512 (1983)

[36] Ö. Tamer, N. Dege, G. Demirtaş, D. Avci, Y. Atalay, M. Macit, A. Alaman Agar, Spectrochim. Acta A 117, 13 (2014).

[37] N. Dege, N. Şenyüz, H. Bati, N. Günay, D. Avci, Ö. Tamer, Y. Atalay, Spectrochim. Acta A 120, 323 (2014).

[38] R.G. Pearson, Proc. Natl. Acad. Sci. 83, 8440 (1986).

[39] A.E. Reed, L.A. Curtiss, F. Weinhold, Chem. Rev. 88, 899 (1988)

[40] D.G. Truhlar, J. Chem. Phys. 82, 2418 (1985).

[41] S. Sebastian, N. Sundaraganesan, Spectrochim. Acta A 75, 941 (2010). 
TABLE VI

Second order perturbation theory analysis of Fock matrix in NBO basis for the title compound at B3LYP and HF methods with $A 2$ basis set

\begin{tabular}{|c|c|c|c|c|c|c|c|c|c|c|c|c|c|}
\hline \multirow{3}{*}{$\begin{array}{c}\text { Donor } \\
(i)\end{array}$} & \multirow{3}{*}{$\begin{array}{c}\text { Type } \\
(j)\end{array}$} & \multirow{3}{*}{$\begin{array}{l}\text { Acceptor } \\
\text { (i) }[e]\end{array}$} & \multirow{3}{*}{$\begin{array}{l}\text { Type } \\
(j)[e]\end{array}$} & \multicolumn{5}{|c|}{ 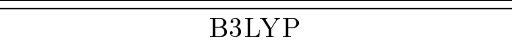 } & \multicolumn{5}{|c|}{$\mathrm{HF}$} \\
\hline & & & & \multicolumn{2}{|c|}{ Occup. } & \multirow{2}{*}{\begin{tabular}{|c|}
$E(2)$ \\
[a.u.] \\
\end{tabular}} & \multirow{2}{*}{$\frac{\Delta E(j i)}{(i)[e]}$} & \multirow{2}{*}{$\frac{F(i . j)}{(j)[e]}$} & \multicolumn{2}{|c|}{ Occup. } & \multirow{2}{*}{\begin{tabular}{|c|}
$E(2)$ \\
{$[$ a.u.] }
\end{tabular}} & \multirow[t]{2}{*}{$\Delta E(j i)$} & \multirow[t]{2}{*}{$F(i . j)$} \\
\hline & & & & {$\left[\frac{\mathrm{kcal}}{\mathrm{mol}}\right]$} & [a.u.] & & & & {$\left[\frac{\mathrm{kcal}}{\mathrm{mol}}\right]$} & [a.u.] & & & \\
\hline \multirow[t]{2}{*}{$\mathrm{C} 25-\mathrm{C} 26$} & $\pi$ & $\mathrm{N} 21-\mathrm{C} 22$ & $\pi^{*}$ & 1.58507 & 0.38596 & 20.35 & 0.27 & 0.07 & 1.58005 & 0.37835 & 49.11 & 0.47 & 0.14 \\
\hline & & $\mathrm{C} 23-\mathrm{N} 24$ & $\pi$ & & 0.33769 & 18.72 & 0.27 & 0.07 & & 0.33643 & 43.01 & 0.48 & 0.13 \\
\hline $\mathrm{C} 27-\mathrm{H} 27 \mathrm{~A}$ & $\sigma^{*}$ & N1-N2 & $\sigma^{*}$ & 1.98492 & 0.03170 & 5.69 & 0.91 & 0.06 & 1.98857 & 0.02425 & 6.94 & 1.40 & 0.09 \\
\hline \multirow[t]{2}{*}{$\mathrm{C} 2-\mathrm{C} 22$} & $\sigma^{*}$ & $\mathrm{~N} 2-\mathrm{C} 27$ & $\sigma^{*}$ & 1.97278 & 0.03803 & 4.00 & 0.98 & 0.06 & 1.97492 & 0.02683 & 4.96 & 1.47 & 0.08 \\
\hline & & N21-C26 & $\sigma^{*}$ & & 0.01510 & 3.44 & 1.20 & 0.06 & & 0.01262 & 4.29 & 1.72 & 0.08 \\
\hline $\mathrm{C} 22-\mathrm{C} 23$ & $\sigma^{*}$ & N21-C22 & $\sigma^{*}$ & & & & & & 1.98481 & 0.01915 & 3.76 & 1.82 & 0.07 \\
\hline $\mathrm{N} 21-\mathrm{C} 22$ & $\sigma^{*}$ & $\mathrm{C} 22-\mathrm{C} 23$ & $\sigma^{*}$ & & & & & & 1.98397 & 0.03304 & 3.46 & 1.96 & 0.07 \\
\hline \multirow[t]{4}{*}{ N21-C22 } & $\pi$ & $\mathrm{C} 25-\mathrm{C} 26$ & $\pi^{*}$ & 1.69569 & 0.28235 & 23.26 & 0.32 & 0.08 & 1.70090 & 0.28744 & 45.38 & 0.56 & 0.14 \\
\hline & & $\mathrm{C} 23-\mathrm{N} 24$ & $\pi$ & & 0.33769 & 18.24 & 0.31 & 0.07 & & 0.33643 & 37.03 & 0.55 & 0.13 \\
\hline & & $\mathrm{C} 2-\mathrm{O} 2$ & $\pi$ & & 0.25039 & 6.66 & 0.34 & 0.04 & & & & & \\
\hline & & $\mathrm{LP}^{*}(1) \mathrm{C} 2$ & & & & & & & & 0.68128 & 10.51 & 0.38 & 0.06 \\
\hline $\mathrm{C} 2-\mathrm{N} 2$ & $\sigma^{*}$ & N1-C1 & $\sigma^{*}$ & & & & & & 1.98877 & 0.00835 & 3.22 & 2.03 & 0.07 \\
\hline N1-C1 & $\pi$ & C11-C12 & $\pi^{*}$ & 1.91919 & 0.37085 & 8.63 & 0.37 & 0.05 & 1.94959 & 0.35442 & 10.97 & 0.64 & 0.08 \\
\hline C1-C11 & $\sigma^{*}$ & N1-N2 & $\sigma^{*}$ & 1.97229 & 0.03170 & 4.70 & 1.05 & 0.06 & 1.97446 & 0.02425 & 6.25 & 1.57 & 0.09 \\
\hline & & N1-C1 & $\sigma^{*}$ & & & & & & & 0.00835 & 3.91 & 1.82 & 0.08 \\
\hline & & C11-C12 & $\sigma^{*}$ & & & & & & & 0.02243 & 3.00 & 1.72 & 0.06 \\
\hline $\mathrm{C} 23-\mathrm{N} 24$ & $\pi$ & $\mathrm{C} 25-\mathrm{C} 26$ & $\pi^{*}$ & 1.69188 & 0.28235 & 24.42 & 0.32 & 0.08 & 1.68799 & 0.28744 & 50.03 & 0.55 & 0.15 \\
\hline & & $\mathrm{N} 21-\mathrm{C} 22$ & $\pi$ & & 0.38596 & 18.42 & 0.31 & 0.07 & & 0.37835 & 37.45 & 0.54 & 0.13 \\
\hline N21-C26 & $\sigma^{*}$ & $\mathrm{C} 2-\mathrm{C} 22$ & $\sigma^{*}$ & 1.98455 & 0.07317 & 3.48 & 1.23 & 0.06 & 1.98599 & 0.06166 & 4.19 & 1.77 & 0.08 \\
\hline N14-O141 & $\pi$ & N14-O141 & $\pi^{*}$ & 1.98566 & 0.62694 & 7.59 & 0.32 & 0.05 & 1.98949 & 0.53634 & 6.00 & 0.62 & 0.06 \\
\hline & & $\mathrm{C} 13-\mathrm{C} 14$ & $\pi$ & & 0.39660 & 3.14 & 0.46 & 0.04 & & & & & \\
\hline & & $\mathrm{LP}(3) \mathrm{O} 142$ & & 1.45055 & 12.37 & 0.18 & 0.08 & & & & & & \\
\hline $\mathrm{LP}(1) \mathrm{N} 2$ & & $\mathrm{C} 27-\mathrm{H} 27 \mathrm{~A}$ & $\sigma^{*}$ & 1.60569 & 0.01233 & 4.68 & 0.66 & 0.06 & 1.70789 & 0.01172 & 7.22 & 1.02 & 0.08 \\
\hline & & $\mathrm{C} 27-\mathrm{H} 27 \mathrm{~B}$ & $\sigma^{*}$ & & 0.01202 & 4.46 & 0.66 & 0.05 & & 0.01089 & 6.38 & 1.02 & 0.08 \\
\hline & & N1-C1 & $\pi^{*}$ & & 0.21554 & 33.57 & 0.28 & 0.09 & & 0.13616 & 42.86 & 0.58 & 0.15 \\
\hline & & $\mathrm{C} 2-\mathrm{O} 2$ & $\pi^{*}$ & & 0.25039 & 43.34 & 0.30 & 0.11 & & & & & \\
\hline & & $\mathrm{LP}^{*}(1) \mathrm{C} 2$ & & & & & & & & 0.68128 & 115.83 & 0.37 & 0.21 \\
\hline $\mathrm{LP}(2) \mathrm{O} 2$ & & $\mathrm{C} 2-\mathrm{C} 22$ & $\sigma^{*}$ & 1.85710 & 0.07317 & 18.84 & 0.66 & 0.10 & 1.89097 & 0.06166 & 26.28 & 1.09 & 0.15 \\
\hline & & $\mathrm{C} 2-\mathrm{N} 2$ & $\sigma^{*}$ & & 0.08850 & 25.88 & 0.67 & 0.12 & & 0.06794 & 35.23 & 1.16 & 0.18 \\
\hline $\mathrm{LP}(3) \mathrm{O} 2$ & & $\mathrm{LP}^{*}(1) \mathrm{C} 2$ & & & & & & & 1.50115 & 0.68128 & 416.19 & 0.31 & 0.33 \\
\hline $\mathrm{LP}(1) \mathrm{N} 1$ & & $\mathrm{~N} 2-\mathrm{C} 27$ & $\sigma^{*}$ & 1.91375 & 0.03803 & 10.66 & 0.70 & 0.08 & 1.93399 & 0.02683 & 12.49 & 1.17 & 0.11 \\
\hline & & C1-C11 & $\sigma^{*}$ & & & & & & & 0.02517 & 4.21 & 1.29 & 0.07 \\
\hline & & C1-H1 & $\sigma^{*}$ & & 0.03353 & 10.65 & 0.78 & 0.08 & & 0.02589 & 14.49 & 1.21 & 0.12 \\
\hline $\mathrm{LP}(1) \mathrm{N} 21$ & & $\mathrm{C} 25-\mathrm{C} 26$ & $\sigma^{*}$ & 1.91779 & 0.03375 & 8.28 & 0.91 & 0.08 & 1.93419 & 0.02807 & 10.57 & 1.37 & 0.11 \\
\hline & & $\mathrm{C} 2-\mathrm{C} 22$ & $\sigma^{*}$ & & 0.07317 & 3.05 & 0.75 & 0.04 & & 0.06166 & 4.91 & 1.19 & 0.07 \\
\hline & & $\mathrm{C} 22-\mathrm{C} 23$ & $\sigma^{*}$ & & 0.04005 & 9.42 & 0.90 & 0.08 & & 0.03304 & 12.13 & 1.37 & 0.12 \\
\hline & & $\mathrm{C} 26-\mathrm{H} 26$ & $\sigma^{*}$ & & 0.02360 & 3.85 & 0.78 & 0.05 & & 0.01913 & 6.17 & 1.22 & 0.08 \\
\hline LP(1) N24 & & C25-H25 & $\sigma^{*}$ & 1.91886 & 0.02350 & 3.80 & 0.78 & 0.05 & 1.93515 & 0.01921 & 6.12 & 1.22 & 0.08 \\
\hline & & $\mathrm{C} 25-\mathrm{C} 26$ & $\sigma^{*}$ & & 0.03375 & 8.40 & 0.90 & 0.08 & & 0.02807 & 10.82 & 1.37 & 0.11 \\
\hline & & $\mathrm{C} 22-\mathrm{C} 23$ & $\sigma^{*}$ & & 0.04005 & 8.63 & 0.90 & 0.08 & & 0.03304 & 10.93 & 1.37 & 0.11 \\
\hline & & $\mathrm{C} 23-\mathrm{H} 23$ & $\sigma^{*}$ & & 0.02349 & 3.76 & 0.78 & 0.05 & & 0.01889 & 6.04 & 1.22 & 0.08 \\
\hline $\mathrm{LP}(1) \mathrm{O} 141$ & & C14-N14 & $\sigma^{*}$ & 1.98173 & 0.10477 & 4.20 & 1.07 & 0.06 & 1.98190 & 0.08316 & 5.74 & 1.59 & 0.09 \\
\hline $\mathrm{LP}(2) \mathrm{O} 141$ & & C14-N14 & $\sigma^{*}$ & 1.89976 & & 12.21 & 0.56 & 0.07 & 1.92240 & & 17.22 & 1.01 & 0.12 \\
\hline & & N14-O142 & $\sigma^{*}$ & & 0.05483 & 18.95 & 0.72 & 0.11 & & 0.04061 & 25.66 & 1.30 & 0.17 \\
\hline $\mathrm{LP}(1) \mathrm{O} 142$ & & C14-N14 & $\sigma^{*}$ & 1.98174 & 0.10477 & 4.20 & 1.07 & 0.06 & 1.98192 & 0.08316 & 5.74 & 1.59 & 0.09 \\
\hline $\mathrm{LP}(2) \mathrm{O} 142$ & & C14-N14 & $\sigma^{*}$ & 1.89971 & & 12.22 & 0.56 & 0.07 & 1.92231 & & 17.24 & 1.01 & 0.12 \\
\hline & & N14-O141 & $\sigma^{*}$ & & 0.05472 & 18.92 & 0.72 & 0.11 & & 0.04055 & 25.63 & 1.30 & 0.17 \\
\hline $\mathrm{LP}(3) \mathrm{O} 142$ & & N14-O141 & $\pi^{*}$ & 1.45055 & & 163.10 & 0.14 & 0.14 & 1.50191 & 0.53634 & 283.13 & 0.35 & 0.29 \\
\hline
\end{tabular}

$E(2)$ means energy of hyperconjugative interactions(stabilization energy). $\Delta E(j i)$ means energy difference between donor and acceptor $\mathrm{i}$ and $\mathrm{j}$ NBO orbitals. $F(i, j)$ is the Fock matrix element between $\mathrm{i}$ and $\mathrm{j}$ NBO orbitals. 
Hybrid compositions of the title compound at B3LYP and HF methods with 6-311++G(d,p) basis set

\begin{tabular}{|c|c|c|c|c|c|c|c|c|c|c|c|c|}
\hline \multirow{3}{*}{ Bond } & \multirow{3}{*}{ Type } & \multirow{3}{*}{ Atom } & \multicolumn{5}{|r|}{ B3LYP } & \multicolumn{5}{|r|}{$\mathrm{HF}$} \\
\hline & & & Occ & up. $s$ & $p$ & $d$ & \multirow[t]{2}{*}{ NBO } & \multicolumn{2}{|c|}{ Occup.|s } & $p$ & $d$ & \multirow[t]{2}{*}{$\mathrm{NBO}$} \\
\hline & & & \multicolumn{4}{|c|}{$[\%]$} & & \multicolumn{4}{|c|}{$[\%]$} & \\
\hline \multirow[t]{2}{*}{$\mathrm{C} 25-\mathrm{C} 26$} & \multirow[t]{2}{*}{$\sigma$} & $\mathrm{C} 25$ & 49.90 & 37.78 & 62.17 & 0.05 & \multirow[t]{2}{*}{$0.7064\left(s p^{1.65}\right)+0.7078\left(s p^{1.64}\right)$} & 49.91 & 37.62 & 62.28 & 0.10 & \multirow[t]{2}{*}{$0.7065\left(s p^{1.66}\right)+0.7077\left(s p^{1.65}\right)$} \\
\hline & & $\mathrm{C} 26$ & 50.10 & 37.93 & 62.03 & 0.05 & & 50.09 & 37.75 & 62.15 & 0.10 & \\
\hline \multirow[t]{2}{*}{$\mathrm{C} 25-\mathrm{C} 26$} & $\sigma^{*}$ & $\mathrm{C} 25$ & 50.10 & 37.78 & 62.17 & 0.05 & $0.7078\left(s p^{1.65}\right)-7.064\left(s p^{1.64}\right)$ & 50.09 & 37.62 & 62.28 & 0.10 & $0.7077\left(s p^{1.66}\right)-0.7065\left(s p^{1.65}\right)$ \\
\hline & & $\mathrm{C} 26$ & 49.90 & 37.93 & 62.03 & 0.05 & & 49.91 & 37.75 & 62.15 & 0.10 & \\
\hline & & $\mathrm{C} 26$ & 50.33 & 0.00 & 99.94 & 0.06 & & 50.78 & 0.00 & 99.90 & 0.10 & \\
\hline $\mathrm{C} 25-\mathrm{C} 26$ & $\pi$ & $\mathrm{C} 25$ & 50.33 & 0.00 & 99.94 & 0.06 & $0.7094(p)-7.0$ & 50.78 & 0.00 & 99.89 & 0.11 & $0.7126(p)-0$ \\
\hline & & $\mathrm{C} 26$ & 49.67 & 0.00 & 99.94 & 0.06 & & 49.22 & 0.00 & 99.90 & 0.10 & \\
\hline $\mathrm{C} 25-\mathrm{N} 24$ & $\sigma$ & $\mathrm{C} 25$ & 40.81 & 31.77 & 68.13 & 0.10 & $0.6388\left(s p^{2.14}\right)+0.7693\left(s p^{1.84}\right)$ & 40.46 & 32.00 & 67.84 & 0.17 & $0.6361\left(s p^{2.12}\right)+0.7716\left(s p^{1.72}\right)$ \\
\hline & & N24 & 59.19 & 35.23 & 64.69 & 0.09 & & 59.54 & 36.67 & 63.20 & 0.14 & \\
\hline $\mathrm{C} 25-\mathrm{N} 24$ & $\sigma^{*}$ & $\mathrm{C} 25$ & 59.19 & 31.77 & 68.13 & 0.10 & $0.7693\left(s p^{2.14}\right)-0.6388\left(s p^{1.84}\right)$ & 59.54 & 32.00 & 67.84 & 0.17 & $0.7716\left(s p^{2.12}\right)-0.6361\left(s p^{1.72}\right)$ \\
\hline & & $\mathrm{N} 24$ & 40.81 & 35.23 & 64.69 & 0.09 & & 40.46 & 36.67 & 63.20 & 0.14 & \\
\hline & & N21 & 58.48 & 35.64 & 64.28 & 0.08 & & 58.83 & 37.03 & 62.84 & 0.13 & \\
\hline $\mathrm{C} 22-\mathrm{N} 21$ & $\sigma^{*}$ & $\mathrm{C} 22$ & 58.48 & 31.79 & 68.11 & 0.09 & $0.7647\left(s p^{2.14}\right)-0.6443\left(s p^{1.8}\right)$ & 58.83 & 32.00 & 67.85 & 0.15 & $0.7670\left(s p^{2.12}\right)-0.6417\left(s p^{1.70}\right)$ \\
\hline & & N21 & 41.52 & 35.64 & 64.28 & 0.08 & & 41.17 & 37.03 & 62.84 & 0.13 & \\
\hline $\mathrm{C} 22-\mathrm{N} 21$ & $\pi$ & $\mathrm{C} 22$ & 44.32 & 0.00 & 99.90 & 10 & $(p)+0.7462(p)$ & 45.05 & 0.00 & 99.86 & 0.14 & $0.6712(p)+0.7413(p)$ \\
\hline & & N21 & 55.68 & 0.01 & 99.83 & 0.15 & & 54.95 & 0.01 & 99.79 & 0.21 & \\
\hline $\mathrm{C} 22-\mathrm{N} 21$ & $\pi$ & $\mathrm{C} 22$ & 55.68 & 0.00 & 99.90 & 0.10 & $0.7462(p)-0.6$ & 54.95 & 0.00 & 99.86 & 0.14 & $0.7413(p)-0$. \\
\hline & & N21 & 44.32 & 0.01 & 99.83 & 0.15 & & 45.05 & 0.01 & 99.79 & 0.21 & \\
\hline $\mathrm{C} 2-\mathrm{N} 2$ & $\sigma$ & $\mathrm{C} 2$ & 36.50 & 30.78 & 69.11 & 0.11 & $0.6042\left(s p^{2.25}\right)+0.7969\left(s p^{1.8}\right)$ & 36.17 & 31.28 & 68.52 & 0.20 & $0.6014\left(s p^{2.19}\right)+0.7990(s$ \\
\hline & & N2 & 63.50 & 35.68 & 64.28 & 0.04 & & 63.83 & 35.91 & 64.01 & 0.08 & \\
\hline $\mathrm{C} 2-\mathrm{N} 2$ & $\sigma^{*}$ & $\mathrm{C} 2$ & 63.50 & 30.78 & 69.11 & 0.11 & $0.7969\left(s p^{2.25}\right)-0.6042\left(s p^{1.8}\right)$ & 63.83 & 31.28 & 68.52 & 0.20 & $0.7990\left(s p^{2.19}\right)-0.6014\left(s p^{1.78}\right)$ \\
\hline & & N2 & 36.50 & 35.68 & 64.28 & 0.04 & & 36.17 & 35.91 & 64.01 & 0.08 & \\
\hline $\mathrm{C} 2-\mathrm{O} 2$ & $\sigma$ & $\mathrm{C} 2$ & 35.41 & 31.76 & 68.07 & 0.17 & $0.595\left(s p^{2.14}\right)+0.8037\left(s p^{1.54}\right)$ & 35.03 & 33.01 & 66.76 & 0.24 & $0.5919\left(s p^{2.02}\right)+0.8060\left(s p^{1.30}\right)$ \\
\hline & & $\mathrm{O} 2$ & 64.59 & 39.39 & 60.49 & 0.12 & & 64.97 & 43.46 & 56.39 & 0.15 & \\
\hline $\mathrm{C} 2-\mathrm{O} 2$ & $\pi$ & $\mathrm{C} 2$ & 30.99 & 0.92 & 98.63 & 0.45 & $0.5567(p)+0.8307(p)$ & & & & & \\
\hline & & $\mathrm{O} 2$ & 69.01 & 1.02 & 98.86 & 0.12 & & & & & & \\
\hline $\mathrm{C} 2-\mathrm{O} 2$ & $\pi$ & $\mathrm{C} 2$ & 69.01 & 0.92 & 98.63 & 0.45 & $0.8307(p)-0.5567(p)$ & & & & & \\
\hline & & $\mathrm{O} 2$ & 30.99 & 1.02 & 98.86 & 0.12 & & & & & & \\
\hline $\mathrm{N} 2-\mathrm{C} 27$ & $\sigma$ & N2 & 63.69 & 34.15 & 65.83 & 0.03 & $0.798\left(s p^{1.93}\right)+0.6026\left(s p^{3.44}\right)$ & 64.38 & 34.36 & 65.58 & 0.05 & $0.8024\left(s p^{1.91}\right)+0.5968($ \\
\hline & & $\mathrm{C} 27$ & 36.31 & 22.49 & 77.37 & 0.14 & & 35.62 & 22.91 & 76.84 & 0.25 & \\
\hline $\mathrm{N} 2-\mathrm{C} 27$ & $\sigma^{*}$ & N2 & 36.31 & 34.15 & 65.83 & 0.03 & $0.6026\left(s p^{1.93}\right)-0.798\left(s p^{3.44}\right)$ & 35.62 & 34.36 & 65.58 & 0.05 & $0.5968\left(s p^{1.91}\right)-0.8024\left(s p^{3.35}\right)$ \\
\hline & & $\mathrm{C} 27$ & 63.69 & 22.49 & 77.37 & 0.14 & & 64.38 & 22.91 & 76.84 & 0.25 & \\
\hline N2-N1 & $\sigma$ & N2 & 53.55 & 30.09 & 69.83 & 0.08 & $0.7317\left(s p^{2.32}\right)+0.6816\left(s p^{2.99}\right)$ & 53.07 & 29.49 & 70.39 & 0.13 & $0.7285\left(s p^{2.39}\right)+0.6850\left(s p^{2.85}\right)$ \\
\hline & & N1 & 46.45 & 25.06 & 74.81 & 0.13 & & 46.93 & 25.90 & 73.91 & 0.19 & \\
\hline N2-N1 & $\sigma^{*}$ & N2 & 46.45 & 30.09 & 69.83 & 0.08 & $0.6816\left(s p^{2.32}\right)-0.7317\left(s p^{2.99}\right)$ & 46.93 & 29.49 & 70.39 & 0.13 & $0.6850\left(s p^{2.39}\right)-0.7285\left(s p^{2.85}\right)$ \\
\hline & & N1 & 53.55 & 25.06 & 74.81 & 0.13 & & 53.07 & 25.90 & 73.91 & 0.19 & \\
\hline N14-O141 & $\sigma$ & N14 & 49.12 & 31.94 & 67.92 & 0.13 & $0.7009\left(s p^{2.13}\right)+0.7133\left(s p^{3.03}\right)$ & 48.95 & 32.34 & 67.36 & 0.30 & $0.6997\left(s p^{2.08}\right)+0.7145\left(s p^{2.57}\right)$ \\
\hline & & O141 & 50.88 & 24.76 & 75.09 & 0.14 & & 51.05 & 27.96 & 71.93 & 0.11 & \\
\hline N14-O141 & $\sigma^{*}$ & N14 & 50.88 & 31.94 & 67.92 & 0.13 & $0.7133\left(s p^{2.13}\right)-0.7009\left(s p^{3.03}\right)$ & 51.05 & 32.34 & 67.36 & 0.30 & $0.7145\left(s p^{2.08}\right)-0.6997\left(s p^{2.57}\right)$ \\
\hline & & O141 & 49.12 & 24.76 & 75.09 & 0.14 & & 48.95 & 27.96 & 71.93 & 0.11 & \\
\hline N14-O141 & $\pi$ & N14 & 39.55 & 0.00 & 99.75 & 0.25 & $0.6289(p)+0.7775(p)$ & 33.78 & 0.00 & 99.44 & 0.56 & $0.5812(p)+0.8138(p)$ \\
\hline & & O141 & 60.45 & 0.00 & 99.86 & 0.14 & & 66.22 & 0.00 & 99.87 & 0.13 & \\
\hline N14-O141 & $\pi$ & N14 & 60.45 & 0.00 & 99.75 & 0.25 & $0.7775(p)-0.6289(p)$ & 66.22 & 0.00 & 99.44 & 0.56 & $0.8138(p)-0.5812(p)$ \\
\hline & & O141 & 39.55 & 0.00 & 99.86 & 0.14 & & 33.78 & 0.00 & 99.87 & 0.13 & \\
\hline N14-O142 & $\sigma$ & N14 & 49.12 & 31.95 & 67.92 & 0.13 & $0.7009\left(s p^{2.13}\right)+0.7133\left(s p^{3.03}\right)$ & 48.97 & 32.34 & 67.36 & 0.30 & $0.6998\left(s p^{2.08}\right)+0.7144\left(s p^{2.58}\right)$ \\
\hline & & O142 & 50.88 & 24.75 & 75.11 & 0.14 & & 51.03 & 27.93 & 71.96 & 0.11 & \\
\hline N14-O142 & $\sigma^{*}$ & N14 & 50.88 & 31.95 & 67.92 & 0.13 & $0.7133\left(s p^{2.13}\right)-0.7009\left(s p^{3.03}\right)$ & 51.03 & 32.34 & 67.36 & 0.30 & $0.7144\left(s p^{2.08}\right)-0.6998\left(s p^{2.58}\right)$ \\
\hline & & O142 & $|49.12|$ & 24.75 & 75.11 & 0.14 & & 48.97 & 27.93 & 71.96 & $|0.11|$ & \\
\hline
\end{tabular}

